\section{Australian Journal of \\ Crop Science}

AJCS 13(06):1031-1036 (2019)

\title{
Addition of essential oils and inulin for production of reduced salt and fat ham
}

\author{
Rosicleide dos Santos Silva ${ }^{1}$, Alcione dos Santos Lima ${ }^{1}$, Leandro Paulo da Silva ${ }^{1}$, Robson do Nascimento \\ Silva ${ }^{1}$, Emmanuel Moreira Pereira ${ }^{3}$, Fernando Luiz Nunes de Oliveira ${ }^{1}$, Geíza Alves Azerêdo*2
}

\author{
${ }^{1}$ Laboratory of Food Microbiology, Federal Institute of Education, Science and Technology of Pernambuco, Vitória de \\ Santo Antão, Brazil \\ ${ }^{2}$ Laboratory of Food Microbiology, Department of Management and Food Technologic, Federal University of Paraíba, \\ João Pessoa, Brazil \\ ${ }^{3}$ São Paulo State University (Unesp), School of Agricultural and Veterinarian Sciences, Jaboticabal, Brazil
}

*Corresponding author: geazeredo@yahoo.com.br; geiza.azeredo@cchsa.ufpb.br

\begin{abstract}
It has been estimated that approximately $75 \%$ of the human's sodium intake is added during industrial manufacturing. Processed meats can also contain relatively high amounts of saturated fats, and high levels of fat, associated with increased risk of obesity, diabetes and cancers, especially colon cancers. In contrast, dietary fiber intake (ex. inulin) has been associated with health benefits, including a suggested protective effect against colorectal cancer due to an inverse association with colorectal cancer risk. Nutritional and health concerns indicate that consumption of these two elements should be reduced. This study aimed to develop a ham with reduced levels of salt and fat. We added essential oils of oregano and rosemary to preserve the ham as a substitute for fat, for which inulin was also added. Six ham formulations were prepared (control, fat reduction + inulin, salt reduction, salt reduction + essential oils, salt reduction + no fat, and salt reduction + no fat + essential oils). The physical-chemical and microbiological quality parameters were evaluated. The addition of inulin did not interfere with the chemical composition of the formulated ham, presenting itself as a promising alternative for reducing the addition of fat in baked ham. The administration of essential oils in combination caused a significant decrease in native flora of cooked ham. These results suggest that a combination of essential oils and inulin may be a promising alternative in the production of meat products with lower salt and fat levels.
\end{abstract}

Keywords: meat product, natural preservative, food additives.

\section{Introduction}

Meat and its products are highly prone to microbial contamination because they are rich in essential nutrients and are perishable (Jayasena and Jo, 2013). Enterococcus, Carnobacterium, Brochothrix thermosphacta, Pseudomonas, Enterobacter Lactobacillus spp and yeast are microorganisms commonly known to dominate the spoilage microbiota of different meat products (Foulquié-Moreno et al., 2006; Nychas et al., 2008; Vasilopoulos et al., 2008). Additionally, foodborne diseases have emerged as important and growing public health and economic problems in many countries over the last few decades. In the Brazilian Legislation (Resolution RDC n. 12 of January 2, 2001, which establishes the microbiological standards for foods), tolerance limits are established for Coliform microorganisms at $450 \mathrm{C} / \mathrm{g}$, Coagulase positive Staphylococci per gram and Clostridium sulfite reductant at $46 . \mathrm{C}$ of $10^{3}, 3 \times 10^{3}$ and $5 \times 10^{2} \mathrm{UFC} / \mathrm{g}$, respectively, for cooked ham. For this reason, we have been concerned in studying the reduction of the native flora of cooked ham.

Sodium chloride, the main ingredient used in processed meats, is a major source of sodium (Horita et al., 2014) and is responsible for its flavour, preservation, and textural properties (Petracci et al., 2013). It has been estimated that approximately $75 \%$ of the sodium consumed is added during industrial manufacturing (Brown et al., 2009; Anderson, 2010). The largest contributors of sodium are processed meats $(18 \%)$, bread and bakery products $(13 \%)$, dairy products (12\%), and sauces and spreads (11\%) ( $\mathrm{Ni}$ et al., 2010). A high intake of sodium is associated with a greater risk of high blood pressure, which is a major cause of cardiovascular disease and stroke (He et al., 2011). Processed meats can also contain relatively high amounts of saturated fats, associated with increased risk of obesity, diabetes and cancers, especially colon cancers (Aggett et al., 2005). Therefore, nutritional and health concerns indicate that consumption of these two elements should be reduced (Aaslyng et al., 2014; Greiff et al., 2015; Marchetti et al., 2015). Food technologists and nutritionists have been making great efforts to develop novel meat products with low fat, low sodium and antimicrobials, enriched with dietary fiber (Hygreeva et al., 2014). Consumers now prefer natural food additives that may also improve the quality and shelf life of meat products (Fratianni et al., 2010). Plantderived essential oils (EOs) have shown remarkable 
antioxidant properties and antimicrobial potency against spoilage and pathogenic microorganisms in meat and meat products (Jayasena and Jo, 2013; Pavelková et al., 2014). These oils are safe as food additives and certified as "Generally Recognized As Safe" (GRAS) (Lucera et al., 2012). The synergy of Origanum vulgare L. and Rosmarinus officinalis L. essential oils against bacteria has been reported previously. Azerêdo et al. (2011) suggested a synergistic effect of the combined application of these oils against Listeria monocytogenes, Yersinia enterocolitica and Aeromonas hydrophilla.

Dietary fibers such as inulin are functional ingredients that have been used to replace fat, resulting in increased waterbinding capacity, and improved texture of meat products (Rodriguez Furlán et al., 2014). Inulin is is a prebiotic dietary fiber showing excellent properties as a carbohydrate-based fat substitute in relation to its ability to increase viscosity, form gels, provide mouthfeel and texture, and to increase water-holding capacity; thus presenting a good application potential in various food product formulations (Öztürk and Serdaroğlu, 2017). The gel obtained from inulin has a creamy and appropriate consistency, creating a mouthfeel of fat in low- fat food products (Alaei et al., 2018). Inulin is resistant to hydrolysis by animal digestive enzymes but are hydrolyzed and fermented by colon microbiota (Raninen et al., 2011). Dietary inulin is known to exert immunemodulatory effects and induces differentiation in several intestinal cell types to its effects on the gut flora (Barclay et al., 2010), and to inhibit development of colon cancers in animal models (Öztürk and Serdaroğlu, 2017). The aim of the present study was to evaluate the addition of essential oils and inulin in the production of ham with reduced levels of salt and fat.

\section{Results and discussion}

Effect of inulin and essential oils on protein, ash, moisture and fat content in cooked ham

The moisture value showed significant differences $(p<0.05)$ in ham formulations compared to control. The ham with reduced salt, fat and added essential oils exhibited an $8.67 \%$ moisture reduction compared to the commercial product, which may result in a longer shelf life. This may be explained due to the diluent effect of fibre and water binding in the inulin chains that allow easy absorption. Furthermore, inulin acts as a reductant of moisture due to osmotic pressure, reducing the water available in food preparations (Gomes et al., 2007). Huang et al. (2011) showed that with increased level of inulin, the moisture content of the sausage samples was decreased, which was consistent with the results of our study.

Lower values were found for lipid in the formulations in which inulin was added. The formulation with reduced salt content and total inulin replacement of fat exhibited a $44.9 \%$ reduction compared to the control. Reducing the amount of fat and substituting it with inulin were the main reasons for the decreased level of fat in the final product. This makes the product healthier and places it in the reduced-fat category. Menegas et al. (2013) showed that the addition of inulin reduced the fat content, compared to the control group, similar to results obtained in our study. Silva-Vazquez et al. (2018) suggest that animal fat could be replaced with inulin as a strategy for producing stable, more healthfriendly meat batters. Alaei et al. (2018) showed that the use of inulin as a fat substitute could improve physicochemical, textural, color, and sensory properties of chicken sausages. According to Oliveira et al. (2017), the use of essential oil (clove and /or rosemary) has potential to maintain /improve the quality (lipid content, $\mathrm{pH}$ and color) of the meat during its useful life. Resolution 234 made on 21/05/1996 by the Ministry of Health determines that a "reduced fat product" provides a minimum fat reduction of $25 \%$ fat compared to the conventional and low-fat product when the fat content is less than $3 \%$ in solids.

\section{Effect of essential oils on survival of autochthonous microflora in cooked ham}

The effect of salt reduction, with or without inulin or the essential oils of $O$. vulgare and $R$. officinalis (in mixture), on the count of mesophilic bacteria, Enterobacteriaceae, psychrotrophic bacteria, fungi, S. aureus and coliform is shown in Table 1. Reducing salt without the presence of essential oils caused increase in count of mesophilic, psychrotrophic and Enterobacteriaceae bacteria by approximately 2 logarithmic cycles during the 120 hours of refrigerated storage $(p \leq 0.05)$. Moreover, the scores of all microorganisms in the ham receiving essential oils were much lower than those found in other ham formulations ( $p$ $\leq 0.05$ ). According to the results of this work, application of mixture of essential oils caused a significant decrease in these groups (or family) of microorganisms. This behavior was also evidenced by Van Haute et al. (2016), who investigated effect of cinnamon, oregano and thyme essential oils on the microbial shelf life of marinated fish and meat products. They found that these essential oils increase the shelf life of meat products and decrease microbial counts.

Some researchers revealed that the application of oregano essential oil in meat effectively inhibited S.enteritidis and E.coli, with a significant reduction in $E$. coli and $S$. enteritidis viable counts after $6 \mathrm{~h}$ of drying at $55^{\circ} \mathrm{C}$ with $2 \mathrm{~mL}(0.038 \mathrm{~mL}$ L-1 air) and $1.5 \mathrm{~mL}$ (0.028mLL-1 air) of oregano essential oil, respectively. Additionally, these autors recommended that a concentration of $0.75-1.5 \mathrm{~mL}$ of essential oil should be tested in combination with other natural preservatives such as organic acids, essential oils, lysozyme, nisin, conventional preservatives or physical methods according to the hurdle technology concept (Hernández et al., 2017). Pesavento et al. (2015) observed that only $0.5 \%$ concentration of the three tested EOs (Rosmarinus, Thymus and Oregano) could be used as food additives because it does not substantially alter the flavour of the food but is able to act as a bacteriostatic or bactericidal agent against high and low $\left(<10^{2} \mathrm{CFU} / \mathrm{g}\right)$ pathogen concentrations, respectively. In this work, even though the concentration of the oregano essential oils was very low $(0.03125 \%)$, when combined with rosemary essential oil at a concentration of $0.5 \%$. A synergistic response was occurred capable of significantly reducing the microbial counts.

Azerêdo et al. (2011) found a synergistic effect of the combined application of OVEO and ROEO against the bacteria associated with minimally processed vegetables. 
Table 1. Formulations of cooked ham, with or without inulin and with or without essential oils.

\begin{tabular}{|c|c|c|c|c|c|}
\hline \multirow[t]{2}{*}{ Sample } & \multicolumn{4}{|c|}{ Formulation } & \multirow[b]{2}{*}{$\%$ Oil } \\
\hline & Meat (g) & $\%$ Salt & $\%$ Fat & $\%$ Inulin & \\
\hline Control & 3000 & 1 & 10 & - & - \\
\hline Fat reduction and inulin & 3000 & 1 & 5 & 5 & - \\
\hline Salt reduction & 3000 & 0.8 & 10 & - & - \\
\hline Salt reduction and essential oils (FIC) & 3000 & 0.8 & 10 & - & $\begin{array}{l}\text { In mixture } \\
\text { OVEO: } 0.3125 \mu \mathrm{L} / \mathrm{mL} \text {; } \\
\text { ROEO: } 5 \mu \mathrm{L} / \mathrm{mL}\end{array}$ \\
\hline Salt reduction and no fat & 3000 & 0.8 & - & 10 & - \\
\hline Salt reduction + no fat + essential oils & 3000 & 0.8 & - & 10 & $\begin{array}{l}\text { In mixture: } \\
\text { OVEO: } 0.3125 \mu \mathrm{L} / \mathrm{mL} \text {; } \\
\text { ROEO: } 5 \mu \mathrm{L} / \mathrm{mL}\end{array}$ \\
\hline
\end{tabular}

Table 2. Count (log of cfu/g) of the microflora in cooked ham exposed to 0 . vulgare and $R$. officinalis (in mixture) essential oils and inulin, with or without salt on days 01 ( $0 \mathrm{~h}$ ) and 05 ( $120 \mathrm{~h}$ ) of cold storage.

\begin{tabular}{|c|c|c|c|c|c|c|c|c|c|c|c|c|}
\hline \multirow{3}{*}{ Treatment } & \multicolumn{12}{|c|}{ Microorganisms } \\
\hline & \multicolumn{2}{|l|}{ Mesophilics } & \multicolumn{2}{|c|}{ Enterobacteriaceae } & \multicolumn{2}{|c|}{ Psychrotrophic } & \multicolumn{2}{|c|}{ Moulds and Yeasts } & \multicolumn{2}{|l|}{ S. aureus } & \multicolumn{2}{|c|}{ Thermotolerant coliforms } \\
\hline & 0 & $120 \mathrm{~h}$ & 0 & $120 \mathrm{~h}$ & 0 & $120 \mathrm{~h}$ & 0 & $120 \mathrm{~h}$ & 0 & $120 \mathrm{~h}$ & 0 & $120 \mathrm{~h}$ \\
\hline Control & $3.5( \pm 0.2)^{\mathrm{a}}$ & $3.88( \pm 0.2)^{b}$ & $<1.0^{\mathrm{a}}$ & $1.27( \pm 0.2)^{\mathrm{a}}$ & $<1.0^{a}$ & $1.79( \pm 0.2)^{\mathrm{a}}$ & $5.82( \pm 0.2)^{b}$ & $6,73( \pm 0.2)^{a}$ & $2.02( \pm 0.2)^{b}$ & $3.54( \pm 0.2)^{b}$ & $<1.0^{\mathrm{a}}$ & $<1.0^{a}$ \\
\hline Fat reduction + inulin & $<1.0^{d}$ & $1.17( \pm 0.4)^{d}$ & $<1.0^{\mathrm{a}}$ & $<1.0^{\mathrm{b}}$ & $<1.0^{\mathrm{a}}$ & $<1.0^{\mathrm{b}}$ & $7.03( \pm 0.3)^{a}$ & $7.47( \pm 0.2)^{\mathrm{a}}$ & $<1.0^{\mathrm{c}}$ & $<1.0^{c}$ & $<1.0^{\mathrm{a}}$ & $<1.0^{\mathrm{a}}$ \\
\hline $\begin{array}{l}\text { Salt reduction + essential } \\
\text { oils }\end{array}$ & $2.07( \pm 0.3)^{b}$ & $1.52( \pm 0.4)^{d}$ & $<1.0^{\mathrm{a}}$ & $<1.0^{\mathrm{b}}$ & $<1.0^{\mathrm{a}}$ & $<1.0^{\mathrm{b}}$ & $2.15( \pm 0.3)^{d}$ & $1.95( \pm 0.2)^{c}$ & $1.53( \pm 0.3)^{b}$ & $<1.0^{\mathrm{c}}$ & $<1.0^{\mathrm{a}}$ & $<1.0^{\mathrm{a}}$ \\
\hline Salt reduction & $4.08( \pm 0.2)^{a}$ & $6.53( \pm 0.2)^{a}$ & $<1.0^{\mathrm{a}}$ & $2.25( \pm 0.3)^{\mathrm{a}}$ & $<1.0^{\mathrm{a}}$ & $2.67( \pm 0.3)^{a}$ & $4.40( \pm 0.2)^{c}$ & $4.95( \pm 0.1)^{b}$ & $4.50( \pm 0.1)^{a}$ & $5.40( \pm 0.2)^{a}$ & $<1.0^{\mathrm{a}}$ & $<1.0^{\mathrm{a}}$ \\
\hline $\begin{array}{l}\text { Salt reduction + no fat + } \\
\text { essential oils }\end{array}$ & $1.15( \pm 0.3)^{b}$ & $<1.0^{\mathrm{d}}$ & $<1.0^{\mathrm{a}}$ & $<1.0^{\mathrm{b}}$ & $<1.0^{\mathrm{a}}$ & $<1.0^{\mathrm{b}}$ & $1.38( \pm 0.4)^{d}$ & $<1.0^{d}$ & $<1.0^{c}$ & $<1.0^{c}$ & $<1.0^{\mathrm{a}}$ & $<1.0^{\mathrm{a}}$ \\
\hline Salt reduction + no fat & $3.53( \pm 0.2)^{a}$ & $5.28( \pm 0.2)^{\mathrm{a}}$ & $<1.0^{\mathrm{a}}$ & $2.20( \pm 0.3)^{a}$ & $<1.0^{\mathrm{a}}$ & $2.06( \pm 0.3)^{a}$ & $3.43( \pm 0.2)^{c}$ & $4.78( \pm 0.2)^{b}$ & $3.39( \pm 0.2)^{a}$ & $4.66( \pm 0.2)^{a}$ & $<1.0^{\mathrm{a}}$ & $<1.0^{\mathrm{a}}$ \\
\hline
\end{tabular}

Means $( \pm S E)$ in the same column with different superscript capital letters are significantly different $(p<0.05)$ according to the Duncan test. 
According to these authors, the increased antimicrobial activity caused by a mixture of OVEO and ROEO could be partially explained by considering the different compounds found in each essential oil. This leads us to suggest that artificial mixtures might be prepared by adding other main constituents present in the EOs to increase the biological activity or verify the contribution of such pure compounds to the final activity (Fratini et al., 2014). Thus, application of essential oils in food systems is an interesting and growing area for researchers whose results could end up having a great use for food industries (Fernández-López and ViudaMartos, 2018).

\section{Materials and methods}

\section{Essential oils and inulin}

OVEO (Origanum vulgare L. Essential Oil - density at 20C: 0.90 ; refractive index at $20^{\circ} \mathrm{C}: 1.47$ ) and ROEO (Rosmarinus officinalis L. Essential Oil - density at 20C: 0.94 ; refractive index at $20 \circ \mathrm{C}$ : 1.51) were purchased from Ferquima Ind. Com. Ltd. (São Paulo, Brazil). The OVEO and ROEO emulsions were prepared in brain heart infusion broth - BHI (Himedia, India) at a range of concentrations (80 $-0.312 \mathrm{~mL} / \mathrm{mL})$ using Tween $80(1 \%$, v/v; Sigma -Aldrich, USA) as an emulsifier (Carvalho et al., 2015, Monte et al., 2014). Inulin was acquired from Clariant S.A. (São Paulo, Brazil).

\section{Treatments}

Six treatments were conducted to test the replacement of pork fat and salt with 5 and $10 \%$ inulin and OVEO $(0.3125 \mu \mathrm{l} / \mathrm{mL})+$ ROEO $(5 \mu \mathrm{l} / \mathrm{mL})$, respectively. The formulations/treatments were: control (no salt and fat reduction); Fat reduction and inulin ( $5 \%$ inulin $+5 \%$ fat); Salt reduction $(0.8 \%$ salt); Salt reduction and essential oils ( $0.8 \%$ salt + OVEO: $0,0.3125 \mu \mathrm{l} / \mathrm{mL}+$ ROEO: $5 \mu \mathrm{l} / \mathrm{mL})$; Salt reduction and no fat $(0.8 \%$ salt $+10 \%$ inulin); Sal reduction and no fat and essential oils $(0.8 \%$ salt + 10\% inulin + OVEO: $0,0.3125 \mu \mathrm{l} / \mathrm{mL}+$ ROEO: $5 \mu \mathrm{l} / \mathrm{mL}$ ).

\section{Sample preparation and cooked ham}

Pork meat was acquired from the Meat Technology Laboratory - Federal Institute of Education, Science and Technology of Pernambuco (Brazil). The $\mathrm{pH}$ of the ham muscles was monitored in order to exclude material outside the normal range (5.5-5.7). The meat and pork fat (lard) were vacuum-packed and stored at $-18^{\circ} \mathrm{C}$ until required for ham production. The meat was boned and cut into cubes of approximately $5 \mathrm{~cm}^{2}$. After this step, grinding was performed, with subsequent addition of the other curing ingredients (antioxidant (1\%), starch (0.5\%), ham condiments $(1 \%)$, sodium glutamate $(0.5 \%)$, and cochonied carmine dye $(0.001 \%)$. The meat and other ingredients were weighed according to the formulations shown in Table 2 . After $20 \mathrm{~h}$ of drainage in a cold room $\left(-4^{\circ} \mathrm{C}\right)$ for ripening, the meat was wrapped in "cook-in" packaging and, soon after, placed into metal pans. These metal pans, in loaded and closed forms, were placed in the cooking tank with hot water $\left(75^{\circ} \mathrm{C}\right)$, where they remained for approximately 2 hours, which is long enough for the temperature in the thermal centre of the product to reach $72^{\circ} \mathrm{C}$, causing coagulation of proteins, destruction of micro-organisms, flavour development and flavour and colour fixation of the product. A total of 3 presses were performed during the 2 hours of cooking. The ham was then sealed into laminated plastic bags of polyamide/polyethylene and chilled overnight at $4^{\circ} \mathrm{C}$. After overnight of cooling, the product was kept at 4 ${ }^{\circ} \mathrm{C}$.

\section{Effect of inulin and essential oils on physical-chemical parameters in cooked ham}

Moisture, protein, fat and ash content were determined according to the AOAC (2005) methods. All chemical determination was performed in duplicate. The Kjeldahl method was used to measure protein concentrations. Ash content was determined using a muffle furnace, and moisture content determination was performed by drying at $105^{\circ} \mathrm{C} \pm 2$ until the samples reached a constant weight.

\section{Effect of essential oils on survival of bacteria in cooked ham (0 and $120 \mathrm{~h}$ of cold storage)}

Twenty-five g samples of ham were aseptically transferred into a sterile stomacher bag containing $225 \mathrm{~mL}$ of sterile peptone water $(1 \mathrm{~g} / \mathrm{L})$ and homogenized for $60 \mathrm{~s}$. Subsequently, a decimal dilution series $\left(10^{-2}-10^{-5}\right)$ was performed in the same diluent and enumeration of the natural flora by pour-plating $1 \mathrm{~mL}$ of the appropriate sample dilutions on Plate Count Agar (Himedia, India) at $37^{\circ} \mathrm{C}(24-48 \mathrm{~h})$ for total mesophilic bacteria and at $6^{\circ} \mathrm{C}$ (7 d) forpsychrotrophic bacteria. Enterobacteriaceae was spread-plated $0.1 \mathrm{~mL}$ onto Eosyne-Metilen-Blue agar (Himedia, India) at $37^{\circ} \mathrm{C}(24 \mathrm{~h})$, Baird Parker agar (Himedia, India) supplemented with $50 \mathrm{~mL} / \mathrm{L}$ of the egg yolk emulsion containing potassium tellurite (3.5\%) (Himedia, India) to count viable S. aureus and fungi were spread-plated on Sabouraud agar (Himedia, India) at $28^{\circ} \mathrm{C}(48-72 \mathrm{~h})$. The results were expressed as log of cfu/mL (Lopéz-Galvéz et al., 2010). Control flasks containing sterile distilled water were tested in the same way.

\section{Statistical analysis}

All assays were made in triplicate on three separate occasions, and the results were expressed as average of the assays. Statistical analysis was performed to determine significant differences $(p \leq 0.05)$ by ANOVA followed by Duncan test. For statistical analysis, the SigmaStat 3.5 computer programme was used.

\section{Conclusion}

The results showed that inulin may be a promising alternative to reduce the added fat in cooked ham because, in the present study, this material did not significantly interfere with the physical and chemical attributes of the product. The mixture of oregano and rosemary essential oils was effective in reducing the native flora microorganism counts during the storage period.

\section{References}

Alaei F, Hojjatoleslamy M, Hashemi Dehkordi SM (2018) The effect of inulin as a fat substitute on the physicochemical and sensory properties of chicken sausages. Food Sci Nutr. 2: 512-519. 
Aaslyng MD, Vestergaard C, Koch AG (2014) The effect of salt reduction on sensory quality and microbial growth in hotdog sausages, bacon, ham and salami. Meat Sci. 96:4755.

Aggett PJ, Antoine JM, Asp NG, Bellisle F, Contor L, Cummings J H (2005) PASSCLAIM. Process for the assessment of scientific support for claims on foods. Consensus on criteria. Europ J Nutr. 44:1-31.

Anderson CAM, Appel L, Okuda N, Brown IJ, Chan Q, HaoL, Ueshima H, Kesteloot H, Miura K, Curb JD, Yoshita K, Elliott P, Yamamoto ME, Stamler J (2010) Dietary Sources of Sodium in China, Japan, the United Kingdom, and the United States, Women and Men Aged 40 to 59 Years: The intermap Study. J A Diet Assoc. 110:736-745.

Association of Official Analytical Chemists (2005) Official methods of analysis of the Association of Official Analytical Chemists.18th edn. Gaithersburg: AOAC.

Azerêdo GA, Stamford TLM, Nunes PC, Gomes Neto NJ, Oliveira MEG, Souza EL (2011) Combined application of essential oils from Origanum vulgare L. and Rosmarinus officinalis $L$. to inhibit bacteria and autochthonous microflora associated with minimally processed vegetables. Food Res Inter. 44:1541-1548.

Barclay T, Ginic-Markovic M, Cooper P, Petrovsky N (2010) Inulin: A versatile polysaccharide with multiple pharmaceutical and food chemical uses. J Exc and Food Chem. 1: 27-50.

Barros JC, Conceicão ML, Gomes Neto NJ, Costa ACV, Siqueira Júnior JP, Basílio Junior ID, Souza EL (2009) Interference of Origanum vulgare L. essential oil on the growth and some physiological characteristics of Staphylococcus aureus strains isolated from foods. Food Sci Technol. 42:1139-1143.

Brown IJ, Tzoulaki I, Candeias V, Elliott P, Bibbins-Domingo K, Chertow GM, Coxson PG, Moran A, Lightwood JM, Pletcher M J, Goldman L (2009) Salt intakes around theworld: implications for public health. Int J Epid. 38:791-813.

Carvalho RJ, Souza GT, Honorio VG, Sousa JP, Conceiçao ML, Maganani M, Souza EL (2015) Comparative inhibitory effects of Thymus vulgaris L. essential oil Against Staphylococcus aureus, Listeria monocytogenes and mesophilic starter co-culture in cheese-mimicking models. Food Microb. 52:59-65.

Cruz CD, Martinez M B, Destro MT (2008) Listeria monocytogenes: an infectious agent scarcely known in Brazil. Food Nutr. 19:195-206.

Foulquié-Moreno MR, Sarantinopoulos P, Tsakalidou E, De Vuyst $L$ (2006) The role and application of enterococci in food and health. Int J Food Micro. 106:1-24.

Fernández-López J, Viuda-Martos M. (2018) Introduction to the Special Issue: Application of Essential Oils in Food Systems. Foods. 7: 56-60.

Fratianni F, Martino LD, Melone A, Feo VD, Coppola R, Nazzaro $F$ (2010) Preservation of chicken breast meat treated with thyme and balm essential oils. J Food Sci. 75:528-535.

Fratini F, Casella S, Leonardi M, Pisseri F, Ebani VV, Pistelli L, Pistelli L (2014) Antibacterial activity of essential oils, their blends and mixtures of their main constituents against some strains supporting livestock mastitis. Phytot. 96:1-7.

Gomes AT, Cereda MP, Vilpox O (2007) Osmotic dehydration: a low-cost technology for development of family farming. Int J M Region Devel. 3:212-226.
Greiff K, Staurem CJ, Nordvi B, Rustad T (2015) Novel utilization of milk-based ingredients in salt reduced fish pudding. Food Sci Tech. 63:1-8.

Gul P, Bakht J (2015). Antimicrobial activity of turmeric extract and its potential use in food industry. J Food Sci Technol. 52:2272-2279.

He FJ, Burnier M, MacGregor GA (2011) Nutrition in cardiovascular disease: salt in hypertension and heart failure. Euor Heart J. 32:3073-3080.

Hernández $H$, Fraňková $A$, Sýkora $T$, Klouček $P$, Kouřimská $L$, Kučerová I, Banout J (2017) The effect of oregano essential oil on microbial load and sensory attributes of dried meat. J Sci Food Agric. 97: 82-87.

Huang SC, Tsai YF, Chen CM (2011) Effect of wheat fiber, oat fiber and inulin on sensory and physicochemical properties of Chinese style sausages. Asian-Australas J Anim Sci. 24: 875-880.

Hygreeva D, Pandey MC, Radhakrishna K (2014) Potential applications of plant based derivatives as fat replacers, antioxidants and antimicrobials in fresh and processed meat products. Meat Sci. 98: 47-57.

Horita CN, Messias VC, Morgano MA, Hayakawa FM, Pollonio MAR (2014) Textural, microstructural and sensory properties of reduced sodium frankfurter sausages containingmechanically deboned poultrymeat and blends of chloride salts. Food Res Int. 66:29-35.

Jayasena DD, Jo C (2013) Essential oils as Potential antimicrobial agentes in meat and meat products: $\mathrm{A}$ review. Trends Food Sci Technol. 34:96-108.

Lopéz-Galvéz $F$, Allende A, Truchado $P$, Martinez-Sánchez A, Tudela JA, Selma MV, Gil MI (2010) Suitability of aqueous chlorine dioxide versus sodiumhypochlorite as an effective sanitizer for preserving quality of fresh-cut lettucewhile avoiding by-product formation. Postharv Biol Technol. 55:53-60.

Lucera A, Costa C, Conte A, Del Nobile MA (2012) Food applications of natural antimicrobial compounds. Food Microbio. 3:1-13.

Marchetti L, Argel N, Andrés SC, Califano AN (2015) Sodiumreduced lean sausages with fish oil optimized by a mixture design approach. Meat Sci. 104:67-77.

Menegas ZL, Colombo Pimentel T, Garcia S, Helena Prodencio S (2013) Dry fermented chicken sausage produced with inulin and corn oil. Physicochemical, microbiological and textural characteristics and acceptability during storage. Meat Sci. 93:501-506.

Monte DFM, Tavares AG, Albuquerque AR, Sampaio FC, Oliveira TCRM, Franco OL, Souza EL, Magnani M (2014) Tolerance response of multidrugresistant Salmonella enterica strains to habituation to Origanum vulgare L. essential oil. Food Microbiol. 5:1-6.

Ni MC, Capelin C, Dunford EK, Webster JL, Neal BC, Jebb SA (2010) Sodium content of processed foods in the United Kingdom: analysis of 44,000 foods purchased by 21,000 households. Am J Clin Nutr. 93:594-600.

Oliveira MJ, Souza KA, Vital ACP, Guerrero A, Valero MV, Kempinski EMBC, Prado IN (2017) Clove and rosemary essential oils and encapsuled active principles (eugenol, thymol and vanillin blend) on meat quality of feedlotfinished heifers. Meat Science. 130:50-57. 
Pavelková A, Kacániová M, Horská E, Rovná K, Hleba L, Petrová J (2014) The effect of vacuum packaging, edta, oregano and thyme oils on the microbiological quality of chicken's breast. Anaerobe. 29:128-133.

Pesavento G, Calonico C, Bilia AR, Barnabei M, Calesini F, Addona R, Mencarelli L, Carmagnini L, Di Martino MC, Lo Nostro A (2015) Antibacterial activity of Oregano, Rosmarinus and Thymus essential oils against Staphylococcus aureus and Listeria monocytogenes in beef meatballs. Food Contr. 54:188-199.

Petracci M. Bianchi M, Mudalal S, Cavani C (2013) Functional ingredients for poultry meat products. Trend Food Sci Tech. 33:27-39.

Santana EHW, Beloti V, Aragon-Alegro LC, Mendonça MBOC (2010) Staphylococcus in food. Arc Bio Ins. 77:545-554.
Silva-Vazquez R, Flores-Giron E, Quintero-Ramos A, Hume M. $E$, Mendez-Zamora $G$ (2018) Effect of inulin and pectin on physicochemical characteristics and emulsion stability of meat batters. CyTA-J Food.16:306-310.

Sirocchi V, Devlieghere F, Peelman N, Sagratini G, Maggi F, Vittori S, Ragaert P (2017) Effect of Rosmarinus officinalis L. essential oil combined with different packaging conditions to extend the shelf life of refrigerated beef meat. Food Chem. 221:1069-1076.

Van Haute S, Raes K, Van Der Meeren P, Sampers I (2016) The effect of cinnamon, oregano and thyme essential oils in marinade on the microbial shelf life of fish and meat products. Food Contr. 68:30-39. 